\title{
Conjunction Meets Negation: A Study in Cross-linguistic Variation
}

\author{
Anna Szabolcsi and Bill Haddican \\ New York University \\ $10 / 6 / 03$
}

\begin{abstract}
The central topic of this inquiry is a cross-linguistic contrast in the interaction of conjunction and negation. In Hungarian (Russian, Serbian, Italian, Japanese), in contrast to English (German), negated definite conjunctions are naturally and exclusively interpreted as 'neither'. It is proposed that Hungarian conjunctions simply replicate the behavior of plurals, their closest semantic relatives. More puzzling is why English-type languages present a different range of interpretations. By teasing out finer distinctions in intonation and context the paper tracks down missing readings and argues that it is eventually not necessary to postulate a radical cross-linguistic semantic difference. In the course of making that argument it is observed that negated conjunctions on the 'neither' reading carry the expectation that the predicate hold of both conjuncts. The paper investigates several hypotheses concerning the source of this expectation.
\end{abstract}

\section{INTRODUCTION*}

Although conjunction, disjunction, and negation are the simplest logical operators, their interaction exhibits robust cross-linguistic differences. Compare the English and the Hungarian examples below:

Negation and disjunction:

(1) Mary didn't take hockey or algebra. can mean 'Mary didn't take hockey and didn't take algebra'

(2) Mari nem járt hokira vagy algebrára.

Mari not went hockey-to or algebra-to cannot mean 'Mary didn't take hockey and didn't take algebra' can mean 'Mary didn't take hockey or didn't take algebra'

\footnotetext{
* This paper benefitted greatly from comments by an anonymous reviewer. We are grateful to Arto Anttila, David Beaver, Sigrid Beck, Laura Rimell, Vivienne Fong, Andrea Gualmini, Martin Hackl, Barry Schein, and Roger Schwarzschild for discussions at various earlier stages. This research was presented at Cornell (April 2002), in the Institute of Linguistics, Budapest (October 2002), at CUNY (March 2003), and at Mayfest (Maryland, May 2003). We thank the audiences of these talks for comments. Last but not least, we are greatly indebted to those fellow linguists who generously helped us with the Bulgarian, German, Hebrew, Italian, Japanese, Russian, and Serbian data; they are named where these languages are discussed. All remaining errors are our own.
} 
Negation and conjunction:

(3) Mary didn't take hockey and algebra. can mean 'Mary didn't take hockey or didn't take algebra'

(4) Mari nem járt hokira és algebrára.

Mari not went hockey-to and algebra-to

cannot mean 'Mary didn't take hockey or didn't take algebra'

can mean 'Mary didn't take hockey and didn't take algebra'

At first blush, one might describe the contrasts as follows. English disjunction and conjunction happily scope below a c-commanding negation and dutifully obey the de Morgan laws, whereas the Hungarian counterparts either must scope above the c-commanding negation or fail to obey the de Morgan laws. Such contrasts are not restricted to English versus Hungarian. Similar to English is German; similar to Hungarian are Russian, Serbian, Italian, and Japanese, among other languages. ${ }^{1}$

The paper first takes up the issue of Hungarian. It argues that although the above facts pertaining to nem...vagy 'not... or' and nem... és 'not... and' initially seem to follow the same pattern, they have different explanations, having to do with polarity sensitivity and plurality, respectively. The paper then focuses on negated conjunctions and investigates how and why Hungarian and English differ in this domain.

The main claims to be made about not...and / nem ... és are as follows.

(i) Both English and Hungarian have a standard Boolean connective that gives rise to 'not both' readings with sentences, quantifiers, predicates, etc. However, its availability for definites seems to correlate with whether connectives in the given language may be nonmetalinguistically focussed.

(ii) In the absence of such focus, Boolean conjunctions shift to a plurality-denoting interpretation in the definite domain. Within the scope of negation, the 'neither' reading follows from the standardly assumed Homogeneity presupposition of distributive predication applied to pluralities. While less prominent than in Hungarian, the 'neither' reading is also available in English.

(iii) Negated conjunctions on the 'neither' reading carry the expectation that the predicate hold of both conjuncts. The paper investigates three hypotheses concerning what the source of this expectation might be, one pertaining to Homogeneity, one to negation, and one to competition.

\section{POSITIVE POLARITY}

Consider first the contrast in (1) and (2). Szabolcsi (2002a,b) argued that the counterparts of or in Hungarian-type languages are positive polarity items (PPIs). Compare the behavior of

\footnotetext{
${ }^{1}$ We thank Thomas Leu, Martin Hackl, Artur Stepanov, Vita Markman, Željko Bošković, Franca Ferrari, and Andrea Gualmini for German, Russian, Serbian, and Italian judgments. We have however not been in a position to consider these languages in as careful detail as we did English and Hungarian. Muromatsu (2002) and Goro (2003) report Hungarian-like facts for Japanese, with some intriguing observations regarding locality conditions. The English judgments reported in this paper are understood to be American English.
} 
vagy in (6) with the well-known behavior of English some in (5). Both resist scoping under clausemate, though not under extraclausal, negation:

a. He didn't see someone.

* 'not>some' i.e. 'He saw no one'

clausemate negation

$\sqrt{ }$ 'some $>$ not'

b. I don't think that he saw someone.

extraclausal negation

$\sqrt{ }$ 'not $>$ some' i.e. 'I think he saw no one'

(6) a. Nem látta Katit vagy Marit.

Lit. 'He didn't see K or M'2

clausemate negation

* 'not $>$ or'

'or $>$ not'

b. Nem hiszem, hogy látta volna Katit vagy Marit. extraclausal negation

'I don't think that he saw K or M'

$\sqrt{ }$ 'not $>$ or'

If so, the absence of the 'not>or' reading in (2) and (6a) does not challenge the Boolean character of Hungarian vagy (Russian and Serbian ili, Italian $o$, Japanese $k a$ ); it can be looked upon as a matter of restricted scope behavior.

It is worth mentioning that the distribution of some and vagy is actually more complex than traditional wisdom would have it. The clause-internal 'not>some' and 'nem>vagy' readings can be rescued if this scopal configuration is placed into a NPI-licensing context. In the examples below the quantifier few, the conditional, and the matrix adversative predicate create NPI-licensing contexts for the bracketed portion of the sentence:

(7) a. Few people believed that you [didn't see someone].

$\sqrt{ }$ 'Few people believed that you saw no one'

b. If you [don't see someone], you are doomed.

$\checkmark$ 'If you see no one, you are doomed'

c. I regret that he [didn't see someone].

$\checkmark$ 'I regret that he saw no one'

(8) a. Kevesen hitték el, hogy [nem láttad Katit vagy Marit].

$\sqrt{ }$ 'not $>$ or'

b. Ha [nem látod Katit vagy Marit], véged.

'If you don't see K or M, you are doomed'

$\sqrt{ }$ 'not $>$ or'

c. Sajnálom, hogy [nem láttad Katit vagy Marit].

'I regret that you didn't see K or M'

$\sqrt{ }$ 'not $>$ or'

\footnotetext{
${ }^{2}$ Lit. indicates a literal translation when the English and the Hungarian interpretations diverge or possibly diverge. We often omit glosses because morphological details are typically irrelevant in this paper.
} 
Szabolcsi (2002a,b) offers an analysis of the rescuing phenomenon. ${ }^{3}$ The details of this analysis are immaterial for present concerns. The data in (7) and (8) are relevant because they allow us to ask whether the explanation of the exclusive 'neither' reading of nem...és 'not...and' in (4) is that és is a PPI and scopes above clausemate negation. We can test whether the interaction of nem and és replicates that of nem and vagy in full detail. It turns out that the similarity does not go beyond the minimal, clausemate negation context. The 'neither' interpretation does not give way to 'not both' if negation is extraclausal or if an NPI-licensor is added on top of $\left[\right.$ nem... és]: ${ }^{4}$

a. Nem látta Katit és Marit.

Lit. 'He didn't see K and M'

* 'not both'

$\sqrt{ }$ 'neither'

b. Nem hiszem, hogy látta volna Katit és Marit.

Lit. 'I don't think that he saw K and M'

* 'not both'

$\sqrt{ }$ 'neither'

c. Ha nem látod Katit és Marit, véged.

Lit. 'If you don't see $\mathrm{K}$ and $\mathrm{M}$, you are doomed'

* 'not both'

$\sqrt{ }$ 'neither'

d. Sajnálom, hogy nem láttad Katit és Marit.

Lit. 'I regret that you didn't see K and M'

* 'not both'

$\sqrt{ }$ 'neither'

We thus conclude that és 'and' is not a positive polarity item; at least, not one belonging to the class that vagy 'or' and some belong to. ${ }^{5}$

\footnotetext{
${ }^{3}$ Szabolcsi observes that PPIs like some and vagy do not scope immediately below the same clausemate antiadditive operators that license strong NPIs like yet, cf. (5a)-(6a), unless that configuration occurs within a larger, broadly speaking decreasing context that licenses weak NPIs like ever, cf. (7)-(8). She proposes that some and vagy exhibit the combined licensing needs of strong and weak NPIs; in the unacceptable cases the PPI is "halfway" licensed. For further details see the references cited.

${ }^{4}$ To make the jargon transparent, we are going to use the 'not both' and 'neither' labels to distinguish the two readings. The latter label is not intended to carry the specific shades of meaning of the neither...nor construction. Section 9 discusses some of the relevant empirical differences. We use the 'not both' and 'neither' labels in order to remain neutral as to what logical structure each reading has.

${ }^{5}$ The differential account of disjunction and conjunction facts in Hungarian-type languages is supported by acquisition data. Takuya Goro's truth value judgment experiments, inspired by Szabolcsi (2002b) and earlier versions of the present work, have shown that Japanese children reach adult-like behavior in interpreting negated conjunctions as `neither' much earlier than in interpreting negated disjunctions as 'I don't know which' (T. Goro, p.c.). Recall that in all major respects Japanese patterns with Hungarian in this domain.
} 


\section{HOMOGENEITY}

Seeking to explain the 'neither' reading of nem...és, it is more promising to notice that definite plurals in both English and Hungarian interact with negation in the same way that Hungarian definite conjunctions do: ${ }^{6}$

(10) He didn't see the girls.

* 'not all the girls'

$\sqrt{ }$ 'none of the girls'

(11) Nem látta a lányokat.

'He didn't see the girls'

* 'not all the girls'

$\sqrt{ }$ 'none of the girls'

The parallelism is in fact not surprising. The plurals literature works on the assumption that definite plurals and definite conjunctions share the same semantics. This is based on their parallel behavior in a variety of contexts. They support collective and cumulative readings in addition to run-of-the-mill distributive ones, see (12)-(14); they introduce text-level discourse referents for pronomial anaphora, see (15); they are not good at making c-commanding indefinites referentially dependent, see (16), etc. To save space, these properties are illustrated using only English:

(12) The girls/Kate and Mary had a beer. 'distributive'

(13) The girls/Kate and Mary lifted up the table together. 'collective'

(14) The girls/Kate and Mary were born in London and Boston. 'cumulative'

(15) Everyone heard the rumor that you had spotted the girls/Kate and Mary. They are wanted for bank robbery.

(16) Six students took these two subjects/hockey and algebra. \#The twelve students graduate in May.

To account for the availability of collective readings in the first place, definite plurals are generally interpreted as denoting pluralities: sets or individual sums. Given the descriptive similarities, Hoeksema $(1983,1988)$ and others have proposed the same interpretation for conjunctions of definites. I.e. Kate and Mary is not interpreted via the strictly Boolean generalized conjunction schema in Partee and Rooth (1983) that is used for the coordination of predicates, quantifiers, etc.; its and is a non-Boolean operator yielding sets or i-sums.

\footnotetext{
${ }^{6}$ Definite plurals are known to tolerate exceptions. This phenomenon is orthogonal to the issue at hand and will be ignored in what follows.
} 
However, the peculiar interaction of plural definites with negation does not yet follow from this semantics. Those few studies of plurality that discuss negation at all invoke a homogeneity presupposition accompanying distributive predication. ${ }^{7}, 8$. Drawing from Löbner and Schwarzschild, Beck (2001) formulates Homogeneity as in (17). $A$ denotes a plurality and * $P$ a pluralized, i.e. distributive one-place predicate; Beck also extends the definition to pluralized, i.e. cumulative two-place relations $* * P$.

$$
\begin{aligned}
& \text { Homogeneity } \\
& \begin{aligned}
* \mathrm{P}(\mathrm{A})= & 1 \text { iff } \forall \mathrm{x}[\mathrm{x} \varepsilon \mathrm{A} \rightarrow \mathrm{P}(\mathrm{x})] \\
& 0 \text { iff } \forall \mathrm{x}[\mathrm{x} \varepsilon \mathrm{A} \rightarrow \neg \mathrm{P}(\mathrm{x})] \\
& \text { undefined otherwise }
\end{aligned}
\end{aligned}
$$

If the general behavior of definite plurals and definite conjunctions are the same, we expect the latter to share Homogeneity. ${ }^{9}$ Hungarian-type languages bear out this expectation quite

\footnotetext{
${ }^{7}$ For example, Link, Schein, Landman, and Winter do not discuss interaction with negation.

${ }^{8}$ As the reviewer points out, The birds are above and below the cloud (Winter 2001) seems like a counterexample to Homogeneity. Whether it is depends on whether one's theory admits or rejects separate cumulative readings. Winter's does not. Beck and Sauerland (2000) argue that cumulativity is necessary, and Beck (2001) makes it an integral part of her discussion of the strongest meaning hypothesis. We propose to follow Beck.
}

${ }^{9}$ If Homogeneity is intimately linked to denoting pluralities (as in (17)) then this explanation of the 'neither' reading is potentially challenged by whatever evidence favors conjunction reduction, i.e. a thoroughly Boolean analysis of definite plurals; and conversely, the exclusivity of the 'neither' reading in Hungarian presents a challenge for the conjunction reduction approach.

One such current theory is Schein's (1998). Schein refers to Collins's (1988) observation that the members of English conjunctions can be modified by a modal - sentential - adverb even on the collective reading (a single unbroken chain):

(i) The Columbia students and possibly the Harvard students formed the unbroken chain around the Pentagon.

Collins proposed the following interpretation for the conjunction (in Schein's wording; we have not seen Collins' ms.):

(ii) (All) the persons(X) such that the Columbia students are among them $(\mathrm{X})$ and possibly the Harvard students are among them $(\mathrm{X})$ (and no one else)...

Schein notes, however, that this interpretation is incorrect. Since every actual Harvard student is possibly a Harvard student, (ii) makes the Harvard students inescapably part of the chain. The crucial ingredient of Schein's own solution is to derive conjunctions from a sentential source, i.e. conjunction reduction, which is essentially equivalent to the plain Boolean interpretation.

But it seems to us that there is a way to interpret (i) without falling into the trap that Schein points out:

(iii) A plurality X such that the Columbia students are in X and possibly the Harvard students are in $\mathrm{X}$ and nothing that is not Columbia st's. or Harvard st's. is in X...

As Z. Szabó (p.c.) notes, this interpretation is unexceptionable if possibly is interpreted epistemically. The conjecture that the modals in conjunctions are epistemic ones is supported by the fact that necessarily, for instance, does not occur here. Thus, data such as (i) do not make the plurality analysis untenable. On the other hand, it is not obvious how Schein's own theory would replicate the predictions Homogeneity makes, without 
straightforwardly. Thus we conclude that the observed 'neither' readings are not due to Boolean conjunctions scoping over the c-commanding negation; they are due to pluralities undergoing homogeneous distributive predication within the scope of negation.

This analysis correctly predicts that when the connective is plausibly Boolean, the 'not both' reading is available. Such is the case with the conjunction of quantifiers: 'every poem and every novel' and 'every poem and more than three novels' are standardly analyzed as undergoing generalized conjunction of the Boolean kind, as in Partee and Rooth (1983).
a. $\quad$ Mari nem olvasott el minden verset és minden regényt. Mari not read every poem-acc and every novel-acc $\sqrt{ }$ 'Mary didn't read every poem or didn't read every novel'
b. Mari nem olvasott el minden verset és háromnál több regényt. Mari not read every poem-acc and three-than more novel-acc $\sqrt{ }$ ' Mary didn't read every poem or didn't read more than three novels'

To take stock, we now understand why Hungarian definite conjunctions exhibit a 'neither' reading. If their sole interpretation is non-Boolean, we also understand why this reading is the only available one. But then the fact that definite conjunction in English do allow 'not both' is surprising. How do they do it and why is the same trick not available in Hungarian? Secondly, the homogeneous plurals analysis makes one expect that the 'neither' reading is as readily available in English as it is in Hungarian; the question here is whether it is factually readily available. We attack both questions starting with the English data, carefully adding considerations pertaining to intonation and context.

\section{STRESSED $A N D$, A BOOLEAN CONNECTIVE}

Corpus data as well as elicited judgments indicate that 'not both' is a readily available reading of not... and in English definites. Despite its prevalence, it turns out not to be an "unmarked" or "default" reading. For the overwhelming majority of speakers we have consulted, it is contingent on stress on the connective, as in (19). When the connective is not stressed, as in (20), then, depending on various factors to be discussed later, speakers either judge not... and to mean 'neither' or they find it marginal or unacceptable. ${ }^{10}$

Mary didn't take hockey AND algebra.

(stressed $A N D$ )

Mary didn't take hockey and algebra.

(i) 'neither'

(unstressed and)

(ii) ?? or *

forcing unusual scopings and without predicting that conjunctions of quantifiers and conjunctions of definites behave alike.

${ }^{10}$ Additionally, the 'not both' reading is possible in sentences like MARY didn't take hockey and algebra, understood as a retort to Susan didn't take hockey AND algebra. We assume that the absence of high pitch on $A N D$ here is phonological, as in second occurrence focus. 
These data suggest that when Mary didn't take hockey and algebra occurs as a more or less isolated written sentence, reaction to it is a result of complex cooperative behavior. Native speakers cannot help endowing the string with an intonation contour that makes it acceptable and, because no context is supplied, they probably come up with one that does not require complex background assumptions. This typically leads to a 'not both' interpretation, but the fact remains that 'not both' is strictly associated with stressed $A N D$.

Where does $A N D$ come from? One possibility is that definite conjunctions uniformly refer to homogeneous pluralities but stress on the connective removes the homogeneity presupposition. (See Schwarzschild 1993:224 for a similar suggestion.) This is reasonable, but it is not obvious how it would account for the fact that conjunctions with stressed AND do not support collective readings.

(21) a. *Mary AND Susan solved the problem together, so they should share the prize.

b. *Mary, Joan, AND Susan solved the problem together, so...

c. *Mary AND Susan are a happy couple.

d. *Mary AND Susan hate each other.

Another possibility, which accounts for (21), is that stressed $A N D$ is a Boolean connective: Mary AND Susan denotes a generalized quantifier somewhat like both Mary and Susan. On this view $A N D$ resembles both and every in that in VP-internal position it does not scope over negation: ${ }^{11}$
a. Mary hasn't taken every course.
* 'every>not'
b. Mary hasn't taken both courses.
* 'both>not'
c. Mary hasn't taken both hockey and algebra.
* 'both>not'
d. Mary hasn't taken hockey AND algebra'
* 'AND>not'

Stressed $A N D$ is however not identical to both... and, since the latter more readily makes a ccommanding indefinite referentially dependent:
a. At least ten students are taking every course.
$\sqrt{ }$ 'every $>$ at least ten'
b. At least ten students are taking both hockey and algebra.
$\sqrt{ }$ 'both $>$ at least ten'
c. At least ten students are taking hockey AND algebra.
? 'AND $>$ at least ten'

\footnotetext{
${ }^{11}$ The narrow scope of $A N D$ is moreover reminiscent of the fact that stressed $O R$ is a polarity sensitive item: it occurs only in decreasing or modal contexts:
}

(i) He hasn't read Aspects OR Syntactic Structures.

(ii) He may read Aspects OR Syntactic Structures.

(iii) * He has read Aspects OR Syntactic Structures.

We thank the anonymous reviewer for discussion. Exploring this connection would take us too far afield from the central topic of this paper, however. 
M. Hackl (p.c.) points out that the assumption that $A N D$ is a Boolean connective is supported by the fact that it exhibits scalar implicatures that are expected only if it has or as its scalar alternative: ${ }^{12}$

Mary hasn’t taken hockey AND algebra. $\Rightarrow$ Mary has taken hockey or algebra.

The implicature arises because the sentence asserts that Mary has not taken both hockey and algebra and, by the Maxim of Quantity, implicates that the stronger alternative i.e. that Mary has not taken either hockey or algebra, is false.

How many and's are there, then? A Boolean and (stressed or unstressed) for general purposes, a non-Boolean and (unstressed) for definites, and a Boolean and (stressed) also for definites? To avoid this proliferation, we propose to follow the general strategy in Hoeksema (1988) and Winter (1998), who start out with a Boolean and for all, and obtain results equivalent to using non-Boolean and from that, under specific semantic conditions. In particular, Winter relies on the fact that names, definites and their conjunctions as generalized quantifiers are principal filters: they all have a unique minimal element. For example, John and Mary denotes the set of all sets that are supersets of $\{\mathrm{j}, \mathrm{m}\} ;\{\mathrm{j}, \mathrm{m}\}$ is its unique minimal element. He introduces a MIN operator that associates $\{\{\mathrm{j}, \mathrm{m}\}\}$ with John and Mary; this will undergo existential and collective rasing in the derivation of collective readings.

In this paper we do not wish to evaluate particular details of Winter's theory. We assume that the general strategy of deriving all and's from a single Boolean source is correct, and propose three additions. One is to acknowledge the Homogeneity presupposition in the interpretation of distributive predication over pluralities like $\{\mathrm{j}, \mathrm{m}\}$, as in Beck (2001). The second is to assume that MIN applies to the appropriate generalized quantifiers unless something specifically "bleeds" it. The third is that stress on and bleeds MIN. In other words, John AND Mary remains Boolean, without Homogeneity and without collective readings.

Why does stress bleed MIN? The anonymous reviewer proposes that the explanation derives from the fact that the function of focus is to invoke alternatives. Boolean and has or as its alternative, but non-Boolean and does not. Likewise, it is not clear what would count as an alternative for and after MIN applies to the generalized quantifier.

The observation that stressed $A N D$ is responsible for the 'not both' reading of English definite conjunctions may help explain why the Hungarian counterparts lack such a reading, i.e. why (4) is unambiguous: $:^{13}$

${ }^{12}$ More precisely, Mary hasn't taken hockey AND algebra implicates that Mary has taken hockey but not algebra. This is probably due the fact that stressed $A N D$ has an asymmetrical scalar implicature:

(i) a. The Hungarian translation of Homer preserves the content AND the meter. 'the content and even the meter'

b. \# The Hungarian translation of Homer preserves the meter AND the content. 'the meter and even the content'

${ }^{13}$ (4) is compatible with Mary having taken hockey or algebra if hockey-and-algebra was a single combined course. Cf. Mary didn't have fish and chips for dinner is very compatible with her having had steamed sea bass. 
(4) Mari nem járt hokira és algebrára.

Mary not went hockey-to and algebra-to

$\sqrt{ }$ 'neither'

* 'not both'

Hungarian generally allows only metalinguistic focus on connectives. (To our knowledge the same holds for Russian, Serbian, and Italian.) For example, the Hungarian counterparts of (25) and (27) with stressed connectives are entirely unacceptable. The acceptable Hungarian versions have stresses on the two conjuncts, indicating that the conjunction as a whole is focussed:

(25) Mary speaks (only) Spanish, but Kate speaks Spanish AND Japanese.

(26) a. *Mari (csak) spanyolul beszél, Kati viszont spanyolul ÉS japánul (beszél). Mary only Spanish speaks Kate however Spanish and Japanese speaks

b. Mari (csak) spanyolul beszél, Kati viszont SPANYOLUL és JAPÁNUL (beszél). Mary only Spanish-in speaks Kate but Spanish-in and Japanese-in speaks.

(27) Mary may go to London, but Kate may go to London OR Paris.

(28) a. *Mari Londonba mehet, Kati viszont Londonba VAGY Párizsba (mehet). Mary London-to go-may, Kate however London-to or Paris-to go-may

b. Mari Londonba mehet, Kati viszont LONDONBA vagy PÁRIZSBA (mehet). Mary London-to go-may, Kate but London-to or Paris-to go-may

The connective can be focussed only when an utterance in the immediately preceding discourse is repeated and corrected, much like in (29):

(29) He didn't buy oxES, he bought oxEN.

(30) A: Úgy tudom, hogy Mari elmehet Londonba és Párizsba. so know-I that Mary go-may London-to and Paris-to.

B: $\quad$ Rosszul tudod. wrongly know-you

Mari nem Londonba ÉS Párizsba, hanem Londonba VAGY Párizsba mehet. Mary not London-to AND Paris-to but London-to OR Paris-to go-may 'My understanding is that Mari is allowed go to London and Paris. - Wrong. It is not London AND Paris but London OR Paris where Mary is allowed to go.'

The reason for this restriction is probably not that these words are too small to bear stress. For example, vagy has a paired version where it may well be stressed (VAGY te, VAGY én 'either you or me, not both'). Whatever the explanation might be, we observe that Hungarian simply does not have the tool that English uses to retain the Boolean reading of definite conjunctions, and we conjecture that this is responsible for the absence of such a reading in Hungarian.

In sum, all languages have a Boolean 'and' that operates on quantifiers, predicates, sentences, etc. and may in principle scope above or below negation. However, it appears that 
only under stress does it operate on names and definites. Languages that do not allow nonmetalinguistic stress on connectives therefore lack a 'not both' reading in definite conjunctions. Expression of this reading requires an overtly quantificational connective, in Hungarian $X$ is, $Y$ is ' $\mathrm{X}$ also, $\mathrm{Y}$ also = both $\mathrm{X}$ and $\mathrm{Y}$ ':

(31) Péter (nem) beszélt Katival is és Marival is.

Peter (not) spoke Kati-with also and Mari-with also

'Peter spoke / didn’t speak with both Kathy and Mary'

\section{THE 'NEITHER’ READING IN ENGLISH: A PREVIEW}

In section 3 the 'neither' reading of definite conjunctions was traced to their commonalities with plural definites like the girls. It was pointed out that (i) plural definites denote pluralities (sets or individual sums); (ii) distributive predication over pluralities carries a Homogeneity presuppositon; (iii) conjunctions of definites exhibit the same general properties and are therefore thought to have the same plurality denotations; ergo, (iv) distributive predication over pluralities denoted by conjunctions of definites should also carry a Homogeneity presupposition. Within the scope of negation this results in a 'neither' reading.

This reasoning holds equally of Hungarian and English, wherefore we expect that the 'neither' reading is equally available in both languages. Is this really so?

In Hungarian, the 'neither' reading is quite natural and by default available, irrespective of the nature of the conjuncts and irrespective of whether a rich context is provided. Some speakers of English have comparable intuitions. However, the majority of American English speakers we consulted have more nuanced judgments. Recall example (3), where hockey and algebra are two subjects that are not stereotypically associated with each other. When presented with this example without a specific discourse context, the majority of our informants judge that unless and is stressed, the acceptability of the sentence is outright questionable. They comment that the 'neither' reading would require or or nor in the place of and:

?? Mary didn't take hockey and algebra. (unstressed and) 'neither'

Mary didn't take hockey or / nor algebra. 'neither'

But the same speakers readily accept 'neither' readings of slightly different examples.

Postverbal versus topicalized conjunction:

(33) a. ?? Mary didn't take hockey and algebra.

b. Hockey and algebra, Mary didn't take.

Postverbal versus subject conjunction:

(34) a. ?? The petition wasn't signed by the president and the janitor. 
b. The president and the janitor didn't sign the petition.

Mere examples versus exhaustive list:

(35) a. ?? Mary didn't take hockey and algebra.

b. Of the courses on the list, Mary didn't take hockey and algebra.

Ad hoc conjunctions versus stereotypical pairs:

(36) a. ?? Mary didn't take hockey and algebra.

b. Mary didn't take math and physics.

In addition, a specific discourse context may save or kill an example.

In what follows we focus on speakers with such contrastive judgments and consider the contrasts in turn, including cases where just the background assumptions make a difference.

\section{AND SCOPING ABOVE NEGATON}

Because definite conjunctions denote pluralities, the literature seems to assume that they fall within the scope of negation irrespective of their syntactic position (e.g. Schwarzschild 1993/94). Some of the contrasts observed above argue against this assumption. First recall the topic/subject versus VP-internal contrast:

(33) a. ?? Mary didn't take hockey and algebra.

b. Hockey and algebra, Mary didn't take.

(34) a. ?? The petition wasn't signed by the president and the janitor.

b. The president and the janitor didn't sign the petition.

Similarly, T. Leu (p.c.) points out that while $X$ und $Y$ does not express 'neither' when in the scope of a negative in Swiss German, the same reading is perfect if $X$ und $Y$ is topicalized:

(37) a. Käi Lehrer biätet das Jahr Tschutä und Singä a. no teacher offers this year soccer and singing PRT 'not both'

* 'neither'

b. Tschutä und Singä biätet das Jahr käi Lehrer a. soccer and singing offers this year no teacher PRT 'neither'

(38) Käi Lehrer biätet das Jahr Tschutä odr Singä a. no teacher offers this year soccer or singing PRT 'neither' 
We take these data to indicate that definite conjunctions in subject and topic position scope above negation, as subjects and topics generally do. Remaining close to home, a comparable asymmetry is observed in the interpretation of stressed, Boolean $A N D$ :

(39) a. The petition wasn't signed by the president AND the janitor. 'not both'

b. The president AND the janitor didn't sign the petition.

* 'not both'

Scoping above the c-commanded negation is in no way incompatible with the claim that the conjunctions in (33), (34), and (37) denote pluralities, which are potentially scopeless. On Landman's (2000) theory a plural may enter the sentence either directly or via what he calls scopal quantifying in, SQI: Landman uses the first option to derive cumulative readings (where both arguments of the relation are interpreted distributively but scopelessly) and the second, quantifying-in option for asymmetrical distributive readings. Since SQI is independently available to plurals, it comes for free in interpreting (34b) for example:

(40) SQI ${ }_{n}$ : scopal quantifying-in (Landman 2000: 194):

Let $\phi$ be of type $t$ and $\alpha$ the unique expression stored under index $n$ in $S_{\phi}$ :

$\mathrm{SQI}_{\mathrm{n}}[\alpha, \phi]=\operatorname{APPLY}[\lambda \mathrm{x} . \forall \mathrm{xn} \varepsilon \operatorname{AT}(\mathrm{x}): \phi, \alpha]$

Let us now turn to (35b). We thank D. Beaver (p.c.) for pointing out that when a contrast set is provided by the linguistic or extralinguistic context and the conjunction is understood to provide an exhaustive list of what the predicate does not hold of, the 'neither' reading is entirely natural:

(35) b. Of the courses on the list, Mary didn't take hockey and algebra.

In view of the above, we propose that in this case hockey and algebra, although it is in VPinternal position, scopes above negation. This is plausible since such a sentence answers an implicit or explicit negative question:

Which of the courses didn't Mary take?

We need not decide whether all these conjunctions must be quantified in or this is just one of the possible derivations. Relevant to us is the fact that subjects, topics, and exhaustive lists may be quantified in and thus scope above negation. It is thus understandable that even speakers who otherwise have a difficulty with 'neither' readings within the scope of negation easily accept them in these positions.

\section{PACKAGES WITHIN THE SCOPE OF NEGATION}

We now turn to the contrast in (36). Even speakers who require or/nor in (36a) with the ad hoc pair hockey and algebra, find and natural in (36b), where math and physics form a stereotypical pair: they are often linked together in college programs, they are thought to 
require similar skills, etc.

(36) a. ?? Mary didn't take hockey and algebra.

b. Mary didn't take math and physics.

Other examples with stereotypical pairs or with conjuncts that the specific context may package together are also natural on 'neither' readings without further ado:

(42) a. He didn't bring the map and the compass.

b. He didn't notice the scratches and the bruises.

c. He didn't talk to Mr. and Mrs. Smith.

d. He didn't see John and Mary. [understood to be a couple]

All of these will be referred to as "packages".

The importance of packages is this. The data we have reviewed so far indicated that a significant subset of speakers reject or strongly disprefer not $>$ and interpreted as 'neither'. If this were a hard and fast rule, it would have disturbing implications. One might be that English definite conjunctions cannot be interpreted as pluralities. This is implausible, given all the other properties they share with plural definites. Another implication might be that they can be interpreted as pluralities but do not exhibit the Homogeneity presupposition. This is equally implausible, at least given the understanding of Homogeneity as in (17). (17) cares about whether a distributive predicate is applied to a plurality; it does not and cannot matter whether the expression that denotes the plurality is the girls or Mary and Susan.

Against this background, the discovery that all speakers easily admit a 'neither' reading for packages within the scope of negation comes as a relief. It turns out that packaging is not a necessary condition.

\section{NON-PACKAGES WITHIN THE SCOPE OF NEGATION}

So far we have only considered largely decontextualized examples. It is relatively easy to make non-packaged conjunctions acceptable on the 'neither' reading if an appropriate context is provided. Consider the following:

(43) Context: Professor is advising a student who has five more required courses to take. All are offered in the given semester, but the student cannot fit all into her schedule at the same time. The five courses are unrelated to each other. Professor says,

You haven't taken hockey and algebra. Why don't you sign up for them now?

As above, hockey and algebra are not a stereotypical package; nor are they the only courses the student still has to take; nor does the context link them together to the exclusion of other required courses. Nevertheless, the 'neither' reading is perfectly acceptable. (43) shows that English does not draw a sharp line between packages and non-packages. Both can be interpreted as 'neither'. Therefore the homogeneous plurality interpretation of distributive predication must in principle be generally available. 
do:

(44) Context: Student asks Professor to recommend courses from the catalog that will contribute to a nice balanced curriculum. Professor says,

a. \# You haven't taken hockey and algebra. Why don't you take them?

b. You haven't taken hockey or algebra. Why don't you take them?

Corpus data may be used to corroborate the impressions gleaned from (43) versus (44). The following data are among those turned up by a Google search for "don $t * * *$ and", etc. on one day in May 2003; they most plausibly carry the 'neither' reading: ${ }^{14}$

(45) a. Don't blame consulting firms and I-banks

b. Don't call area 809 and other Caribbean codes

c. Winter's coming - but don't abandon the yard and garden

d. Don't Let Sports Sprains and Strains Sideline You

e. Why don't Bonnie B. Barr and Michael B. Leyden answer their mail ...

f. We don't have dancing girls and corporate boxes, but this is the oldest rugby league club in Australia

g. Don't Let the Feminists and Cloners Lead Your Members Astray

h. Don't help the spammers and hackers!

i. Don't forget seat belts and depend on air bags, ...

j. Don't Cut Tributaries, Streams, and Wetlands Out of the Clean Water Act

k. Don't get plastic tarps and duct tape just yet ...

1. Don't waste your energy and intellect on ignorance

m. I Don't See My Templates and Custom Lists. What Happened?

n. Why doesn't God prevent evil and suffering?

o. Teen Doesn't Care about Schoolwork and Hygiene

p. Border doesn't block dirty air and water

q. Golf doesn't have training camp and overpriced exhibition games.

r. ASW's online store doesn't work with Opera and iCab.

s. Features, Ease of Use, Stability, Speed, "doesn't work on Mac and Linux".

t. Mike doesn't work with Messenger and Paltalk

u. Mailing List ls doesn't show directories and links in WU-FTPD 2.6.

v. restore icon doesn't work in Word and Pwrpoint

w. She likes animals, nature, and me. She doesn't like violence, poaching, and meat.

x. Okay, so maybe heart disease doesn't show itself for years, but that doesn't mean it doesn't exist in kids and teens

y. EU won't divulge passengers' race and religion

z. Why didn't "everything" include "mew" and "im"?

\footnotetext{
${ }^{14}$ As the reader may easily confirm, each such search will find over a million tokens of a negated auxiliary separated from and by three arbitrary words. Most of the examples have to be discarded because and is not within the scope of the negation (Don't miss it! Bonnie and Clyde...). Many of the relevant ones, especially those involving conjoined VPs, will obviously carry the 'not both' interpretation. We did not include such examples in the list.
} 
Some of these examples clearly involve what may be called packages (sprains and strains, the feminists and cloners, evil and suffering, etc.) but many others do not. For example, Mac and Linux are far from being a stereotypical pair. What makes the use of and natural in (45s) is that the customer expects a product to work on both Mac and Linux (among other systems, presumably). In general, strikingly many of the relevant examples express complaints, i.e. failed expectations, of some sort.

This squares well with the contrast between (43) and (44). In the context of (43), You haven't taken hockey and algebra is natural, because although unrelated, both courses are required, while in the context of (44), the same sentence is not natural, because these courses are not required at all. In other words, in (43) it is normal or expected for the student both to take hockey and to take algebra, while in (44) it is not.

\section{AND VERSUS OR AND NEITHER...NOR}

Similar insights are obtained if the same sentence is contrasted with some alternatives. $(46 \mathrm{~b}, \mathrm{c})$ are alternatives to (46a) in the sense that all three sentences require that you have not taken hockey and you have not taken algebra. (46a) with not... and suggests that it is normal or expected to take both hockey and algebra, though not necessarily simultaneously. (46b) with not...or makes no such suggestion; it sounds like mentioning two examples of courses you have not taken. Finally, (46c) with neither...nor resembles (46b) in that it does not suggest that normally both courses are taken; it suggests, however, that these two courses are under discussion and checks them off one by one.

$\begin{array}{lc}\begin{array}{l}\text { normal or } \\ \text { expected } \\ \text { to take both }\end{array} & \begin{array}{l}\text { hockey and } \\ \text { algebra dis- } \\ \text { course salient }\end{array} \\ \text { yes } & \text { no } \\ \text { no } & \text { no } \\ \text { no } & \text { yes }\end{array}$

The same effect is observed in (47)--(48), which work the same way in Hungarian and English.

(47) Sajnálom, hogy nem jártam hokira és algebrára.

'I regret that I didn't take hockey and algebra' = I didn't take either, and it would have been good if I had taken both

(48) Sajnálom, hogy nem jártam hokira vagy algebrára.

'I regret that I didn't take hockey or algebra' = I didn't take either, and it would have been good if I had taken at least one of them

In the same spirit, the comparison of (49) and (50) illustrates a case where és/and is not appropriate. Imagine the consulate of a country where people are filling out visa applications. The application form lists the questions in Spanish and English. You see an applicant staring 
at the blank form in front of him and say,

(49) \#Ez a fickó nem tud angolul és spanyolul, így nem tudja kitölteni a kérdôívet. this guy not knows English and Spanish so not can out.fill-inf the form-acc 'This guy doesn't know English and Spanish, so he cannot fill out the form'

(50) Ez a fickó nem tud se angolul, se spanyolul, így nem tudja kitölteni a kérdôívet. this guy not knows nor English nor Spanish so not can out.fill-inf the form-acc 'This guy knows neither English nor Spanish, so he cannot fill out the form'

We know that although the form offers two languages, the applicant is supposed to use only one of them. (49) with és/and is inappropriate; it seems to suggest that knowledge of both languages is relevant and needed. (50) with se $X$, se $Y^{\prime}$ nor $\mathrm{X}$, nor $\mathrm{Y}^{\prime}$ is appropriate, because it indicates that languages $\mathrm{X}$ and $\mathrm{Y}$ were considered one by one; also, $\mathrm{X}$ and $\mathrm{Y}$ are the salient options in the discourse situation. ( $S e X$, se $Y$ 'nor $\mathrm{X}$, nor $\mathrm{Y}^{\prime}$ is the negative concord version of $X$ is, $Y$ is 'both $\mathrm{X}$ and $\mathrm{Y}^{\prime}$ ')

\section{0 'NEITHER': AN INTERIM SUMMARY}

This paper argues that the 'neither' reading of conjunctions within the scope of negation follows from the semantics that conjunctions share with plurals. The preceding two sections have demonstrated that this reading is indeed widely available in English too. Therefore the basic job of the semantic analysis is done.

Nevertheless, some further interesting questions arise:

(51) What explains the fact that the 'neither' reading is most natural with packages and in cases where there is a contextual expectation for the predicate to hold of both conjuncts? (In short, where do the restrictions come from?)

(52) What explains the fact that the restrictions in (51) are significantly stronger in English than in Hungarian, according to both elicited judgments and corpus data?

This paper will not be able to offer satisfactory answers to these questions; they must be left for further research. However, we have investigated several potential explanations; the following sections lay them out and indicate why they do not seem to settle the issues. The discussion will be brief and informal, because we believe that at this stage the argument does not require elaborate formalization.

\section{HOMOGENEITY AS A SOURCE OF THE RESTRICTIONS}

A very natural source of the restrictions would be the Homogeneity presupposition ${ }^{15}$ On one implementation, the "expected both" suggestion observed in the foregoing sections is construed as a presupposition, which must be supported by the context or else accommodated

\footnotetext{
${ }^{15} \mathrm{We}$ thank the anonymous reviewer for suggestions on this point.
} 
by the hearer. Homogeneity gives rise to the "expected both" presupposition in contexts where $\mathrm{P}$ is expected to hold of at least $\mathrm{X}$ or $\mathrm{Y}$. If $\mathrm{P}$ is true of $\mathrm{X}$, then Homogeneity entails that $\mathrm{P}$ holds of both $\mathrm{X}$ and $\mathrm{Y}$. Thus, in the expectation-worlds where $P(X)$ is true even $P(X$-and- $Y)$ is true.

This account correctly distinguishes between the contextual demands associated with packages and non-packages. Suppose that it is expected that students take math or take physics. If math and physics are stereotypically grouped together in curricula, then this expectation amounts to a stronger one, namely, that they take both. Therefore the "expected both" presupposition is by default satisfied, and Mary didn't take math and physics 'Mary took neither' is felicitous out of the blue. On the other hand, hockey and algebra are not stereotypically grouped together, wherefore Mary didn't take hockey and algebra 'Mary took neither' is felicitous only if it is known that specifically in the given context there is an expectation for Mary to take both courses, as was the case in example (43). In the absence of established knowledge, the hearer must accommodate the dual expectation. The visa application situation (49) shows that accommodation may be impossible and the use of and may be outright infelicitous.

Because Homogeneity pertains to $P(X$-and- $Y)$ in positive environments as well, this account predicts that "expected both" is present in affirmatives. The following example indicates that in contexts where expectations matter this may indeed be correct. Imagine a situation where a detective is assigned to watch the entrance and the swimming pool of a house. They are on opposite sides of the house, wherefore it cannot be taken for granted that there is a spot from where they can be watched simultaneously. In this case both... and seems preferable to plain and:

(53) ?\# Jones climbed up a tree from which he could see the entrance and the pool very well.

Jones climbed up a tree from which he could see both the entrance and the pool very well.

But there is another prediction that is more difficult to confirm. The presupposition under discussion ought to come in two different flavors, "expected both" and "expected neither". When there is an expectation for at least $P(X)$ or $P(Y)$ to be false, Homogeneity entails that both are expected to be false. If the context indeed supports that, and should be felicitous. Relevant contexts are not easy to construct but here is an attempt:

(55) A: We will only take this program to a country that has eradicated tuberculosis and malaria.

B: ?\# This country indeed does not have tuberculosis and malaria.

B': This country indeed has neither tuberculosis nor malaria.

As (55) shows, this context prefers neither...nor, contrary to what we expect.

Likewise, this account makes the somewhat paradoxical prediction that if there is no initial expectation whatsoever of either $P(X)$ or $\neg P(X)$, then and is completely free, because Homogeneity does not generate any presupposition regarding expectations. In fact, affirmative examples generally bear out this prediction. (56) is felicitous out of the blue: 
Mary took hockey and algebra.

But negative examples like (44) seem to indicate that this is not correct. Recall that in (44) we have a lack of expectations, rather than a negative expectation, regarding hockey and algebra:

(44) Context: Student asks Professor to recommend courses from the catalog that will contribute to a nice balanced curriculum. Professor says,

a. \# You haven't taken hockey and algebra. Why don't you take them?

b. You haven't taken hockey or algebra. Why don't you take them?

In sum, Homogeneity is an intuitively plausible source of the restrictions in (51) but it is not clear to us how it might derive the exact patterning of the data.

\section{NEGATION AS A SOURCE}

Although the contrast in (53)-(54) indicates that "expected both" may be present in affirmatives, (56) shows it is absent from affirmatives in contexts without any expectations regarding $\mathrm{P}(\mathrm{X})$. Martin Hackl (p.c.) has proposed an elegant way to derive it from a general felicity condition on negation, as in (57):

(57) Felicity Condition on not $p$ : not $p$ presupposes/implicates that $\mathrm{p}$ is normal or was expected.

As a motivation for (57), Hackl observes that (under normal circumstances) John was yelling and John wasn't breathing are felicitous, but John wasn't yelling and John was breathing are not.

It seems to us that (57) is too strong and the effect observed in connection with yelling versus breathing is probably due to informativity. Naturally, not $p$ and As was expected, not $p$ are fully felicitous sentences types. Additionally, Hackl's observation that (under normal circumstances) John was breathing, similarly to John wasn't yelling, is infelicitous entails that a comparable condition should be imposed on plain non-negated $p$ as well; this is now called into question by the felicity of the type Naturally, $p$ and As was expected, $p$.

Specifically, it is difficult to see how a condition pertaining solely to negation would account for the differential acceptability of definite plurals and definite conjunctions within its scope. Suppose a person witnessed a crime committed by a single individual. The police show the witness two pictures that they have on file. Clearly, there is no expectation for her to have seen both men at the crime scene. In this context (58) is still perfect but (59a) is marginal, even though the noun phrases refer to the same plurality:

(58) I have never seen these guys.

(59) a. ?? I have never seen the tall guy and the fat guy / this guy and that guy.

b. I have never seen the tall guy or the fat guy / this guy or that guy. 


\section{EMERGENCE OF THE UNMARKED?}

We have not yet considered the possibility that 'expected both' is an independent presupposition, much like Homogeneity itself. There are two reasons why this does not seem viable. 'Expected both' cannot be directly associated with and or with distributive predication, because Mary took hockey and algebra and Mary did not take hockey and algebra do not carry equal amounts of the expectation.

In sum, 'expected both' does not seem to be a permanent component of the meaning of $P(X$-and- $Y)$, directly or in view of Homogeneity, nor does it seem to derive simply from the presence of negation. A logical possibility that suggests itself is that $P(X$-and- $Y)$ is an unmarked form whose interpretation does not solely depend on its inherent content, but also on its relation to other elements in opposition to it (Jakobson 1932). This approach has two novel features as compared to the ones discussed above. One, it shifts the interpretive burden away from not... and. Two, it makes crucial use of what other linguistic expressions the negated conjunction competes with in the expression of the same truth conditional content.

As was pointed out in section 9, not>and, not>or, and neither...nor are true under the same conditions (although they are false under slightly different ones, since Homogeneity is a presupposition). But let us now turn the table and assume, in addition, that or and neither...nor have an independence condition associated with them. Stalnaker (1975) and Zimmermann (2000) propose that one disjunct must not entail the other. As the anonymous reviewer notes, this is too strong, witness (60):

He doesn't live in L.A. or even in California.

The condition might thus be a conventional implicature, which is not strictly a precondition for truth and is detachable. More pertinent to the present discussion, we assume that the notion relevant to us is not one of logical independence, but independence in terms of some contextually given set of practical considerations C. As a first approximation, we define independence simply as the absence of the expectation we found in not $>$ and:

(61) The propositions $\mathrm{p}$ and $\mathrm{q}$ are independent $\mathrm{i}_{\mathrm{C}}$ if there is no expectation $\mathrm{C}_{\mathrm{C}}$ that both $\mathrm{p}$ and $\mathrm{q}$ be true. ${ }^{16}$

Thus, (46) may be recast as follows:
a. not-P(X and $Y)$ is true only if $\neg \mathrm{P}(\mathrm{X})$ and $\neg \mathrm{P}(\mathrm{Y})$
[by Homogeneity]
b. $\operatorname{not}-P(X$ or $Y)$ is true
iff
$\neg \mathrm{P}(\mathrm{X})$ and $\neg \mathrm{P}(\mathrm{Y})$, and implicates that
c. $P($ neither $X$ nor $Y$ ) is true iff
$\mathrm{P}(\mathrm{X})$ and $\mathrm{P}(\mathrm{Y})$ are independent ${ }_{\mathrm{C}}$
$\neg \mathrm{P}(\mathrm{X})$ and $\neg \mathrm{P}(\mathrm{Y})$, and implicates that
$\mathrm{P}(\mathrm{X})$ and $\mathrm{P}(\mathrm{Y})$ are independent $\mathrm{C}$, and
$\mathrm{X}$ and $\mathrm{Y}$ are discourse salient

\footnotetext{
${ }^{16}$ Frank (1997) and Zvolenszky (2002) observe an important problem for Kratzer's semantics for modals. Zvolenszky proposes that modal propositions be interpreted as normative facts about the world of evaluation. But we do not attempt to develop (61) in more precise terms here, using either approach to modality, because, as we show in section 14, empirical facts do not support the competition hypothesis as strongly as one would wish.
} 
A speaker who wishes to convey $\neg \mathrm{P}(\mathrm{X})$ and $\neg \mathrm{P}(\mathrm{Y})$ can choose from at least these three distinct options. She is supposed to choose the one that fits best with the context; thus, if $\mathrm{P}(\mathrm{X})$ and $\mathrm{P}(\mathrm{Y})$ are independent $\mathrm{C}_{\mathrm{C}}$, she is supposed to choose not...or or neither...nor. Thus, use of not... and will convey "expected both" without this being part of its permanent meaning.

This latter part of the reasoning might be expressible either in terms of Gricean conversational implicatures or in terms of bidirectional Optimality Theory; two approaches that are very close to each other although, to our knowledge, their relationship has only been explored in a preliminary fashion; see Blutner (n/d).

This proposal correctly predicts the use of not... and will not ambiguously convey either "expected both" or "expected neither". The reason is that, by brute force, we defined independence $\mathrm{C}_{\mathrm{C}}$ so that it covers all cases except when both $\mathrm{P}(\mathrm{X})$ and $\mathrm{P}(\mathrm{Y})$ are expected. This removes a problem that arose in connection with deriving "expected both" from Homogeneity. Similar reasoning might also explain why the effect is much weaker in affirmative environments. Here plain and competes with both...and. In Optimality Theory, the fact that there is only one competitor, which is in addition syntactically more complex may account for the wider distribution of plain and. If the reasoning is framed in Gricean terms, the conventional implicature of both... and may be more specific than that of or, thus leaving more space for plain and.

Finally, the present proposal might offer an answer to the question in (52), namely, why speakers of Hungarian (Russian, Serbian, Italian, Japanese...) judge negated conjunctions to be so much more neutral and natural on the 'neither' reading than their English (German, ...) speaking counterparts. Recall the observation, elaborated in section 2, that disjunctions are positive polarity items in the former languages. Therefore, the main competitor is absent: Hungarian nem...és does not compete with nem...vagy for the expression of 'neither'. The only competitor is $s e . .$, se... 'neither...nor...', which is both syntactically more complex and requires a kind of discourse salience that conjunction and disjunction themselves do not.

\section{PROBLEMS FOR THE COMPETITION ACCOUNT}

It is a crucial and attractive feature of the competition account that its predictions are contingent on exactly what linguistic expressions are available for the expression of the given meaning. Now we test the predictions in three different environments in Hungarian. Let us consider three cases.

(63) és 'and' is in the environment of clausemate negation.

Competitors: se..., se... 'neither...nor'

(64) és 'and' is in the environment of clausemate negation, but this constellation is embedded under a NPI-licensor.

Competitors: vagy 'or' and se..., se... 'neither...nor'

(65) és 'and' is in the complement of nélkül 'without'.

Competitors: none.

Case (63) was discussed in section 13 and was claimed to bear out the predictions. The 
background for (64) was presented in section 2: example (8) demonstrated that in this "rescuing" environment, Hungarian disjunctions behave exactly like English disjunctions, hence they compete with conjunctions. The contrast in (47)-(48) of section 9 actually relied on this fact in demonstrating that when vagy is available for competition, "expected both" is quite clear in és. So far, so good. But consider now (65). Nélkül 'without' blocks positive polarity items, wherefore vagy is ruled out as a competitor, just as in (63). But nélkül 'without' does not license se..., se... 'neither...nor' in strict negative concord languages like Hungarian. Thus és 'and' has no competitor.

The competition account predicts that in case (65), X és Y nélkül 'lit. without X and Y' is appropriate independently of contextual expectations. Specifically, it should sound entirely natural even if it is outright unexpected for the predicate to hold of both $\mathrm{X}$ and $\mathrm{Y}$. Unfortunately, this expectation is not borne out. The data in (66)-(67) are at best marginal. These intended meanings must be expressed using some circumscription.

(66) Tudom, hogy nem szereted az édeset.

'I know that you don't like sweet things'

\#? Ezt az ételt cukor és édesítôszer nélkül készítettem.

this the dish-acc sugar and sweetener without prepared-I

Lit. 'I prepared this dish without sugar and (artificial) sweetener'

(67) Csengettek, miközben öltöztem.

'The bell rang while I was dressing'

\# Szoknya és farmer nélkül nyitottam ajtót.

skirt and jeans without opened-I door-acc

Lit. 'I opened the door without a skirt and a pair of jeans'

In this environment, és ought to be immune to "expected both", but it is not. This indicates that "expected both" is not just a product of competition - or at least not in any straightforward way.

The cross-linguistic line of explanation also faces a problem. The competition account would work best if all languages fell either into the English type or the Hungarian type:

(68) English, German:

disjunction not a PPI -- negated conjunctions more difficult on the 'neither' reading

(69) Hungarian, Russian, Serbian, Italian, Japanese:

disjunction a PPI -- negated conjunctions natural on the 'neither' reading

In fact, we are aware of a third type, which resembles English in one crucial respect but Hungarian in another: 
The good news is that the division of labor between conjunctions and disjunctions in these latter languages conforms to our generalizations. The following Modern Hebrew paradigm was constructed by Edit Doron (p.c.):

(71) lo macati ba'al o me'ahev not I-found husband or lover Lit. 'I didn't find a husband or a lover' = looked for either and found neither

(72) lo macati ba'al ve me'ahev not I-found husband and lover Lit. 'I didn't find a husband and a lover' = looked for both and found neither

(73) lo macati lo ba'al ve lo me'ahev not I-found not husband and not lover Lit. 'I found neither a husband nor a lover' = two separate searches, both failed

(74) lo macati ba'al VE me'ahev not I-found husband AND lover Lit. 'I didn't find both a husband and a lover' implies that a husband was found

(75) lo macati gam ba'al ve gam me'ahev not I-found also husband and also lover Lit. 'I didn't find both a husband and a lover'

The bad news is in these languages negated conjunctions and negated disjunctions are equally natural in their own spheres; especially in Bulgarian they may even be interchangeable. This contrasts with the fact that the majority of our English and German informants express a strong preference for negated disjunctions in situations without a very clear expectation for both $\mathrm{P}(\mathrm{X})$ and $\mathrm{P}(\mathrm{Y})$ to be true. The Modern Hebrew and the Bulgarian data indicate that this may not be derivable from competition from disjunctions.

In sum, at least the simple form of the competition hypothesis outlined in section 13 is found wanting, just as the hypotheses relating "expected both" to Homogeneity or negation.

\footnotetext{
${ }^{17}$ We thank Edit Doron, Julia Horvath, Erez Levon, Eytan Zweig, and Boyana Stamenova for data and discussion.

${ }^{18}$ The Bulgarian data come from a chatroom corpus with 64 tokens involving negated conjunctions or disjunctions, collected and annotated for this project by Boyana Stamenova. The fact that Bulgarian may use $i$ 'and' and ili 'or' interchangeably is nicely illustrated by the following example, where the same person uses both connectives in the same sense in the same sentence:
}

(i) Само един въпрос Пуфи - защо смяташ, че предвижданията НЕ СЕ ОПРЕДЕЛЯТ от харесването и нехаресването, одобрението или неодобрението.

'Only one question Puffy - why do you think that the predictions are not based on the like and dislike, the approval or disapproval' (bold facing by B.S.) 


\section{CONCLUSION}

The starting point of this paper was the observation that in Hungarian(-type languages) negation interacts with disjunction and with conjunction in a more restricted fashion than in English (or German). We first argued that in Hungarian the disjunction facts are due to polarity sensitivity, while the conjunction facts follow from the plurality semantics that definite conjunctions are generally thought to share with definite plurals. Distributive predication applied to pluralities carries a Homogeneity presupposition. To explain the absence of an additional Boolean and in the definite domain we observed that it is only available when the connective can be non-metalinguistically focussed; a possibility which is present in English(-type languages) but not in Hungarian(-type languages).

The starting point of the second half of the paper was the observation that the 'neither' reading due to plurality semantics should be as available in English as much as it is in Hungarian - but where the conjunction certainly falls within the scope of negation this does not initially seem to be true. Discussing stereotypically packaged as well as ad hoc conjunctions we argued that 'neither' readings are in fact available; thus the central semantic claim in supported.

In the course of making that argument, we observed a presupposition/implicature accompanying negated conjunctions that was dubbed "expected both". In the last sections we asked where "expected both" comes from. We outlined three hypotheses that look promising but eventually do not work quite as well as they should. We did this in the hope of promoting further research on the subject.

\section{REFERENCES}

Anttila, Arto and Vivienne Fong (2002), Variation, ambiguity, and noun classes in English. To appear in Lingua, special issue on Variation in form versus variation in meaning.

Beck, Sigrid (2001), Reciprocals are definites. Natural Language Semantics 9: 69-138.

Beck, Sigrid and Uli Sauerland (2000), Cumulation is needed: a reply to Winter (2000).

Natural Language Semantics 8:349-371.

Blutner, Reinhard (n/d), Some aspects of optimality in natural language interpretation.

Rutgers Optimality Archive 389-0400.

Collins, Christopher (1988) Conjunction adverbs. Ms., M.I.T.

Goro, Takuya (2003), Japanese disjunction and positive polarity. Ms. U. of Maryland.

Hoeksema, Jack (1983), Plurality and conjunction. In A. ter Meulen, ed., Studies in Modeltheoretic Semantics. Foris, Dordrecht.

Hoeksema, Jack (1988), The semantics of exception phrases. In J. van der Does and J. van Eijck, eds., Quantifiers: Logic and Language. CSLI Publications, Stanford.

Frank, Anette (1997), Context Dependence in Modal Constructions. Unpublished doctoral dissertation, U. of Stuttgart.

Jakobson, Roman (1932), Structure of the Russian verb. reprinted in L. R. Waugh and M. Halle, eds., Roman Jakobson. Russian and Slavic Grammar. pp. 1-14. Mouton, Berlin. 1984.

Landman, Fred (2000), Events and Plurality. Kluwer, Dordrecht. 
Link, Godehard (1983), A logical analysis of plurals and mass terms: a lattice-theoretic approach. In R. Bäuerle et al., eds., Meaning, Use and Interpretation in Language. pp. 302-323. de Gruyter, Berlin.

Löbner, Sebastian (1998), Polarity in natural language: Predication, quantification and negation in particular and characterizing sentences. Linguistics and Philosophy 23: 213-308.

Muromatsu, Keiko (2002), Disjunctions, conjunctions and negation in Japanese. Ms., AMC and NYU.

Partee and Rooth (1983), Generalized conjunction and type ambiguity. In R. Bäuerle et al., eds., Meaning, Use and Interpretation in Language. pp. 361-383. de Gruyter, Berlin.

Schein, Barry (1993), Plurals and Events. MIT Press, Cambridge.

Schein, Barry (1998), Conjunction reduction redux. Ms., USC and http://cognet.mit.edu/Books/celebration/ .

Schwarzschild, Roger (1993/4), Plurals, presuppositions, and the sources of distributivity. Natural Language Semantics 2: 201-249.

Stalnaker, Robert (1975), Indicative conditionals. Philosophia 5: 269-286.

Szabolcsi, Anna (2002a), Positive polarity—negative polarity. To appear in Natural Language and Linguistic Theory.

Szabolcsi, Anna (2002b), Hungarian disjunctions and positive polarity. In Kenesei István and Péter Siptár, eds., Approaches to Hungarian 8. pp. 219-240. Akadémiai Kiadó, Budapest.

Winter, Yoad (2000), Flexible Boolean Semantics. PhD dissertation, Utrecht.

Winter, Yoad (2001), Plural predication and the strongest meaning hypothesis. Journal of Semantics 18: 333-365.

Zimmermann, Thomas Ede (2000), Free choice disjunction and epistemic possibility. Natural Language Semantics 8: 255-290.

Zvolenszky, Zsófia (2002), Is a possible-worlds semantics of modality possible? A problem for Kratzer's semantics. In B. Jackson, ed., Proceedings of SALT XII, pp. 339-359.

Cornell U., Ithaca. 